\section{A PESSOA MEDICADA E O HIV/AIDS: SUBJETIVIDADE, ADESÃO AO TRATAMENTO E BIOPOLÍTICAS}

\author{
Medicated Person and HIV/AIDS: Subjectivity, Accession to \\ Treatment and Biopolitics
}

\section{La Persona Medicada y el VIH/SIDA: Subjetividad, Adhesión al Tratamiento y Biopolíticas}

\section{La Personne Médicalisée et le VIH/SIDA: Subjectivité, Adhésion au Traitement et Biopolitiques}

\section{Resumo}

O objetivo deste artigo é interrogar as implicações do uso da medicação no processo de subjetivação das pessoas vivendo com HIV/AIDS (PVHA) e a adesão ao tratamento. Problematizou-se o lugar central da medicação no discurso da saúde sobre o tratamento dessas pessoas. Trata-se de uma pesquisa qualitativa. Utilizou-se de entrevistas semiestruturadas, com a seguinte pergunta disparadora: “como é, para você, viver com o HIV/AIDS?”. Foram entrevistados 6 sujeitos, sendo 2 mulheres e 4 homens, todos eles usuários de um SAE (Serviço de Atendimento Especializado em DST/AIDS) no Recife-PE. Utilizou-se uma amostragem acidental e intencional. A referência tomada para construir uma teorização a partir dos achados foi inspirada no pensamento de Michel Foucault, especialmente na genealogia do sujeito. Aponta-se como Foucault não possui instrumentos prontos para conduzir suas pesquisas. O que faz são inquirições empíricas precisas sobre áreas e campos muito específicos, sem pretensões globais ou gerais sobre seus campos de estudo. Realizouse uma analítica do sujeito, e não uma análise do discurso no formato tradicional, que deve ser compreendida como a problematização de processos de subjetivação que se dão pela articulação entre regimes de verdade e formas éticas de relação consigo e com o outro, uma genealogia do sujeito. Destacam-se os referenciais ao biopoder e à biopolítica nesses processos de subjetivação de PVHA. A AIDS parece ter circulado como um discurso e serviu como experiências que participaram na formatação de sujeitos, produzindo corpos dóceis e operacionalizando uma governabilidade sobre o corpo individual e da população. Essa gerência da vida fica bem evidente na adesão ao tratamento, observando-se o discurso médico-científico coordenando as formas de subjetivação das PVHA e suas maneiras de conduzir seus tratamentos, o uso da medicação e a adesão, mostrando como o discurso sobre a AIDS foi articulado por vários dispositivos e passou a governar a vida.

Palavras-chave: AIDS; processos de subjetivação; adesão ao tratamento; biopolíticas; Foucault.

\section{Abstract}

The purpose of this article is to question on the implications of the use of medication in the subjective process of people with HIV / AIDS (PVHA) and adherence to treatment. The central place of medication in the health discourse on the treatment of these people was discussed. This is a qualitative research, which used semi-structured interviews, from the following triggering question "how is, for you, living with HIV/AIDS?” There were 6 subjects interviewed, 2 women and 4 men, all of them, members of a Specialized Care Service (SAE) in STD / AIDS in Recife / PE. We used an accidental and intentional sampling. The reference

\section{Biopolítica e Subjetividades Contemporâneas}

\section{Ricardo Lima ${ }^{(1)}$ \\ Cristina Almeida ${ }^{(2)}$ \\ Luciana Vieira ${ }^{(3)}$}

1) Psicólogo Clínico e psicoterapeuta, Mestre em Psicologia Social (UFPB) e Doutor em Psicologia Clínica (UNICAP).

2) Doutora em Psicologia pela Universidad de Deusto, Espanha. Professora adjunto IV da Graduação em Psicologia e da Pós-graduação em Psicologia Clínica da Universidade Católica de Pernambuco. Coordenadora Geral da Pós-graduação da Universidade Católica de Pernambuco (desde 2010).

3) Mestre em Psicopatologia Fundamental e Psicanálise - Université de Paris VII e Doutora em Saúde Coletiva pelo IMS -UERJ. Professora adjunta do Programa de Pós-graduação em Psicologia da UFPE. 
taken to build a theory from the findings was inspired by Michel Foucault's thought, especially in the subject's genealogy. It points out that Foucault does not have instruments prepared to conduct his researches, what he does is accurate empirical inquiries about areas and very specific fields without global or general claims about his fields of study. An analytic of the subject was carried on, and not a discourse analysis as in the traditional format, which must be understood as the questioning of subjective processes that occurs by the relationship between regimes of truth and ethical forms of relationship with yourself and the other, a genealogy of the subject. It is noteworthy the references to biopower and biopolitics in these subjective processes of PVHA. AIDS seems to have circulated as a speech and served as experiences that participated in the formatting of subjects, producing docile bodies and operationalizing governance on the individual body and population. This management of life is evident in the adherence to treatment, observing the medical-scientific discourse coordinating the forms of subjectivity of PVHA and their ways of conducting their treatments, medication use and adherence, showing how the discourse on AIDS iwas articulated by various devices and passed to govern life

Keywords: AIDS; subjective processes; adherence to treatment; biopolitics; Foucault.

\section{Resumen}

El objetivo de este artículo es cuestionar acerca de las implicaciones del uso de medicinas en el proceso de subjetivación de las personas con VIH/SIDA (GIPA) y la adhesión al tratamiento. Se problematizó el lugar central de la medicación en el discurso de la salud bajo el tratamiento de estas personas. Es una investigación cualitativa que se há utilizado de entrevistas semiestructuradas con la siguiente intrigante pregunta: "cómo es, para ti, vivir con VIH/SIDA?". Fueron entrevistados 6 sujetos, siendo 2 mujeres y 4 hombres, todos utilizaban un Servicio de Atendimiento Especializado (SAE) en EST/SIDA en Recife/PE. Se utilizó una muestra accidental e intencional. La referencia para la construcción de una teorización partiendo de los hallazgos fue inspirada en el pensamiento de Michel Foucault, especialmente en la genealogía del sujeto. Se dice que Foucault no posee instrumentos listos para conducir sus investigaciones, lo que hace son precisas indagaciones empíricas acerca de ámbitos y campos muy especificos, sin pretensiones globales o generales acerca de sus campos de estudio. Se realizo una analítica del sujeto y no un análisis del discurso en el formato tradicional, que debe ser comprendida como la problematización de procesos de subjetivación que ocurren por la articulación entre regímenes de verdad y formas éticas de relación con si mismo y con el otro, una genealogía del sujeto. Se sobresalen los referenciales al biopoder y a la biopolítica en estos procesos de subjetivación de GIPA. La SIDA perece haber circulado como un discurso y sirvió como experiencias que participaron en el formateo de sujetos, produciendo cuerpos dóciles y ejecutando una gobernabilidad acerca del cuerpo individual y de la población. Esta gerencia de la vida queda muy notable en la adhesión al tratamiento, observando el discurso médico-cientifico coordinando las formas de subjetivación de las GIPA y sus maneras de conducir sus tratamientos, el uso de la medicación y la adhesión, enseñando cómo el discurso acerca del SIDA fue articulado por muchos dispositivos y pasó a gobernar la vida.

Palabras clave: SIDA; Procesos de subjetivación; Adhesión al tratamiento; Biopoliticas; Foucault.

\section{Résumé}

Le but de cet article est questioner l'engagement de l'usage du médicament dans le processus de subjectivation des personnes infectées au VIH/SIDA et l'adhésion au traitement. On a repenser la place centrale du médicament dans le discours de santé à propos du traitement de ces personnes. C'est une recherche qualificative qui a utilisé des interviews semistructurées à partir de la question suivante: "qu'est-que ça signifie pour vous, vivre avec VIH/SIDA ? "Six personnes ont été interviewées, 2 femmes et 4 hommes, touts utilisateurs du Service d'Attention Spécialisé (SAE) en IST/SIDA au Recife/PE. On a utilisé l'échantillionage accidentel et intentionel. La référence de la construction théorique à partir des résultats a été inspirée par la pensée de Michel Foucault, surtout la généalogie du sujet. Foucault n'avait pas d'outils pour conduire ses recherches, ce qu'il fisait, consistait en faire des recherches empiriques précises dans des domaines très spécifiques, sans des prétentions globaux ou généralisées de ses domaines d'études. On a réalisé une analytique du sujet, et non une analyse du discours au format traditionnel, qui doit être comprise comme la problématisation des processus de subjectivations qui se font à partir de l'articulation entre les régimes de vérité et manières éthiques de relation avec soi et avec l'autre, une généalogie du sujet. On détache les références au biopouvoir et à la biopolitique dans ces processus de subjectivation de PVHA. Le SIDA semble un discours qui a circulé et servi comme des expériences qui ont fait partie de la formation des sujets en produisant des corps dociles et en opérant un gouvernement du corps individuel et de la population. Cette gestion de la vie apparaît clairement à l'adhésion au traitement, ce qui est vérifié au discours médical et scientifique, car il coordonne les manières de subjectivation des PVHA et ses façons de conduire leur traitement, l'usage et l'adhésion au médicament. Cela montre comme le discours à propos de SIDA a été articulé par plusieurs dispositifs et a passé à gouverner la vie.

Mots-clés: SIDA; processus de subjectivation; adhésion au traitement; biopolitiques; Foucault.

A medicina toma um lugar de destaque nos saberes circulantes no período da modernidade. Se a modernidade 
prometeu a felicidade do homem com a sua libertação e racionalidade, a medicina foi um dos meios para promover essa mudança.

$\mathrm{O}$ uso da medicação pelas pessoas que vivem com HIV/AIDS (PVHA), grosso modo, age no sentido de barrar a multiplicação do vírus (carga viral), diminuindo a infecção do organismo e dando a possibilidade de o sistema imunológico (células CD4), em parte, recuperar-se. Uma metáfora muito usada é que as células de defesa, a exemplo das CD4, funcionam como aquelas que comandam o exército de defesa, e sua destruição pelo HIV leva o organismo a um estado de desproteção, que abre porta para as doenças oportunistas. Isso é a AIDS.

Para essas pessoas, dentre todos os exames laboratoriais, a contagem de células CD4 e a medição da carga viral destacam-se como o ponto central de verificação da saúde. A AIDS não tem cura, mas tratamento. E a quantidade de saúde é medida através do desempenho do corpo biológico e, parece, somente dele.

O objetivo deste artigo é interrogar sobre as implicações do uso da medicação no processo de subjetivação das PVHA e a adesão ao tratamento. Será problematizado o lugar central da medicação no discurso da saúde sobre o tratamento dessas pessoas.

Quando se pensa sobre uma definição de adesão, é facilmente perceptível que a sua premissa básica segue os ideais sanitaristas de promoção e prevenção da saúde. Chaiyachatia et al. (2014), por exemplo, define a adesão como:

[...] a extensão na qual a pessoa usa a medicação de acordo com a recomendação médica, inclusive considerando-se o horário, a dose e a consistência. Discutivelmente, adesão é o fator mais crítico para assegurar o sucesso do TARV, porque sem uma boa adesão, a falha no tratamento é provável, levando a uma possível e evitável mortalidade e morbidade ligada ao HIV. Além do que, uma adesão imperfeita aumenta o risco de se desenvolver resistência ao HIV e transmissão do vírus a outras pessoas. (Chaiyachatia, et al., 2014, p. 188)

Porém, faz-se importante, nesse ponto, refletir que certos estudos e posições mostram a adesão apenas ligada à tomada de comprimidos, uma preocupação centrada nos medicamentos e no âmbito sanitarista e biológico do sujeito. O próprio Ministério da Saúde e Programa Nacional de DST e AIDS (PNDA) lançou, em 2007, um manual de referência para profissionais, no qual questiona essa noção, adicionando outros parâmetros e destacando como a adesão deve ser vista:

[...] transcendendo à simples ingestão de medicamentos, devendo ser compreendida de forma mais ampla, incluindo, entre outros aspectos, o fortalecimento das
PVHA, o estabelecimento de vínculo com a equipe de saúde, o acesso à informação, o acompanhamento clinico laboratorial, a adequação aos hábitos e necessidades individuais e o compartilhamento das decisões relacionadas à própria saúde, inclusive para pessoas que não fazem uso de TARV. (Ministério da Saúde, 2007, p. 11)

Dessa forma, Ferreira Neto e Kind (2010) fazem a crítica ao modelo brasileiro de assistência à saúde, definindo-o pautado em uma lógica sanitarista. Ele não oferece um acolhimento efetivo às pessoas em suas singularidades e demandas pessoais, prescrevendo condutas e elegendo estratégias de tratamento, o que parece desconsiderá-las nas suas dimensões políticas como protagonistas sociais, além do direito delas aos seus corpos e à sua saúde.

Ferreira Neto e Kind (2010) destacam o relatório Lalonde como importante marco no entendimento do campo da saúde pública, apontando seus referenciais, centrados em quatro elementos: a biologia, o ambiente (natural e social), o estilo de vida e a organização dos serviços de saúde. Esse relatório centra, claramente, sua ênfase na dimensão do estilo de vida, e essa é uma das críticas que podem ser feitas a ele: as decisões individuais e alguns hábitos pessoais seriam ruins do ponto de vista da saúde, classificados como potenciais riscos autoimpostos. Assim, o relatório inaugura uma fase na saúde de inspiração sanitarista, oriunda da medicina social (iniciada na Europa do século XVIII, com as medidas de higiene social), que dará ênfase ao estilo de vida (Ferreira Neto \& Kind, 2010).

Nos anos 1980, a década seguinte ao relatório Lalonde, haverá o surgimento da epidemia do HIV e do crescimento da AIDS como um grande desafio às políticas públicas de saúde. Toda essa lógica sanitarista será utilizada, destacando-se a questão dos estilos de vida das pessoas infectadas e os comportamentos de risco. Assistir-se-á a um agenciamento das subjetividades humanas, considerandose a maneira como a sexualidade é atingida pelos discursos médicos e sanitaristas.

A abordagem da AIDS a partir desses referenciais colocará mais uma vez em jogo o que Foucault (1976/2000) chamou de biopoder e suas formas de articulação, através daquilo que denominou de biopolítica. A epidemia da AIDS é, sem dúvidas, um exemplo de como os corpos "não dóceis" foram abordados pelos dispositivos do biopoder e politizados, ou seja, transformados em campo de batalha no atravessamento dos discursos circulantes, a exemplo do sanitarista: novas formas de subjetivação precisam ser formatadas e organizadas.

Segundo Agamben (2010), essas novas formas de subjetivação estão ligadas às possibilidades dadas pela maneira como foi construída a lógica da biopolítica. De um lado, o estudo das técnicas políticas, a exemplo dos aparatos de vigilância e controle do Estado, que lhes dotará 
da capacidade de assumir o cuidado com a vida natural dos indivíduos; por outro lado, a contrapartida individual, na qual, através das tecnologias do eu, os indivíduos subjetivados se vinculam a certas identidades e a uma "consciência" de si que vigia sua forma de ser no mundo. A união dessas duas dimensões tornará possível a governabilidade dos corpos, não somente no sentido individual, mas como população.

É nessa dobradura entre os aparatos objetivos (como os programas de saúde do Estado) e as tecnologias de si (as formas de subjetivação) que se desenvolverá a problematização do uso da medicação e da adesão ao tratamento, procurando entender como o manejo do tratamento para as PVHA pode ter-se tornado um discurso importante no gerenciamento da AIDS e seu tratamento.

\section{Caminho Epistemêmico-Metodológico}

Trata-se de uma pesquisa qualitativa. Utilizou-se uma amostragem acidental e intencional, em que os sujeitos devem atender aos critérios de inclusão da pesquisa, nesse caso: estar infectado pelo HIV ou já ter passado por um quadro de AIDS; ser acompanhado ambulatorialmente no SAE (Serviço de Atendimento Especializado em DST/ AIDS) da cidade do Recife-PE, em que se realizou o estudo; e estar em uso de Terapia Antirretroviral (TARV). Todos os participantes da pesquisa contemplam os critérios de inclusão estabelecidos e foram selecionados quando da visita do pesquisador ao SAE, ao longo de suas rotinas de atendimento ambulatorial. Essas pessoas eram indicadas pelos membros da equipe de saúde ou outros usuários do serviço, sendo convidadas a participar da pesquisa.

O SAE é o serviço especializado dentro da organização do Programa Nacional de DST/AIDS e Hepatites Virais (PNDA), que oferece acompanhamento clínico ambulatorial (atenção secundária) multiprofissional às pessoas que apresentem queixas referentes às doenças sexualmente transmissíveis (DST) ou que tenham sido testadas e diagnosticadas com HIV/AIDS.

Esta pesquisa foi aprovada pelo Comitê de Ética em Pesquisa da Universidade Católica de Pernambuco (UNICAP), sob o número 279.481, em 31/05/2013. Todos os entrevistados assinaram o Termo de Consentimento Livre e Esclarecido (TCLE).

\section{Participantes}

Participaram duas mulheres e quatro homens, com idades entre 30 e 68 anos. Três deles se declararam heterossexuais e outros três, homossexuais. Quanto à designação étnico-racial dessas pessoas, considerando-se a autoclassificação, metade se reconheceu como pardo/negro e a outra branco. Quanto às religiões, os entrevistados se mostraram heterogêneos, havendo pessoas de quase todas as religiões mais comuns no Brasil: evangélico, espírita, candomblé, católico, e apenas uma pessoa declarou-se não religiosa (Tabela 1).

Quanto à escolaridade, houve contato com pessoas que tinham desde pós-graduação, passando por uma com o ensino médio completo, até pessoas que somente iniciaram e não concluíram seus estudos. Mais uma vez, nesse aspecto, os sujeitos se mostraram heterogêneos. Com relação à renda média mensal, havia pessoas recebendo desde um salário mínimo e meio até pessoas com até 20 salários mínimos por mês. De todos os entrevistados, apenas um residia em uma cidade do interior de Pernambuco, todos os outros residiam no Recife-PE.

\section{Instrumentos e Procedimentos de Coleta de Dados}

Entrevistas semiestruturadas foram realizadas individualmente com seis pessoas que estavam em tratamento em um SAE do Recife-PE, em ambiente privado. Elas foram iniciadas com a seguinte pergunta disparadora "como é, para você, viver com HIV/AIDS?". Depois, pediu-se a essas pessoas que falassem livremente sobre suas experiências.

Todas as entrevistas foram gravadas digitalmente, para posterior transcrição e análise. Elas se mostraram fluentes, pois as pessoas estavam interessadas em contar suas histórias. Seus nomes foram mudados para serem preservadas suas identidades.

\section{Análise dos Dados}

O fio condutor desta análise é o de uma teorização foucaultiana. Dessa forma, nunca foi objetivo esgotar o tema da AIDS ou do sujeito da AIDS, nem se pretendeu apontar a verdade do sujeito que vive com HIV/AIDS. Além disso, a proposta qualitativa e a visão foucaultiana pressupõem um caráter não universalista ou generalista das discussões. $\mathrm{O}$ intento era problematizar certos aspectos da experiência de viver com HIV/AIDS a partir dos objetos de estudo circunscritos (uso da medicação e adesão ao tratamento), o sujeito e a AIDS.

O que faz Foucault? Ele propõe uma teoria das práticas discursivas, ou seja, uma capacidade de "flutuar no limite das coisas e das palavras" (Fischer, 2012, p. 25). O que interessa é o sujeito, e este não é um produto causal de discursos nem das características e acontecimentos de um tempo. Ele é a expressão de um modo de ser e de fazer a partir das condições discursivas e suas contingências históricas.

Foucault (1978/20) diz que não possui instrumentos prontos para conduzir suas pesquisas. O que faz são inquirições empíricas precisas sobre áreas e campos muito específicos. Enfatiza que não tem pretensões globais ou gerais sobre seus campos de estudo: “[...] e como não há 
Tabela 1

Dados sociodemográficos dos entrevistados

\begin{tabular}{|c|c|c|c|c|c|c|c|}
\hline Apelido & Idade & Etnia/Raça & $\begin{array}{c}\text { Orientação } \\
\text { sexual }\end{array}$ & Instrução & Religião & $\begin{array}{c}\text { Renda Mensal } \\
\text { (R\$) }\end{array}$ & Residência \\
\hline Sandra & 65 anos & Negra & Heterossexual & Pós-graduada & Espírita & $2.500,00$ & Recife/PE \\
\hline Fred & 38 anos & Branco & Homossexual & Pós-graduado & Sem religião & 10 a $15.000,00$ & Recife/PE \\
\hline Agenor & 30 anos & Pardo & Homossexual & Fundamental completo & Candomblé & $1.000,00$ & Recife/PE \\
\hline Renato & 33 anos & Branco & Homossexual & Médio completo & Evangélico & $1.500,00$ & Recife/PE \\
\hline Isabela & 48 anos & Branca & Heterossexual & $\begin{array}{l}\text { Fundamental } \\
\text { incompleto }\end{array}$ & Católica & $1.000,00$ & Primavera/PE \\
\hline Herbert & 33 anos & Negro & Heterossexual & $\begin{array}{c}\text { Fundamental } \\
\text { incompleto }\end{array}$ & Protestante & 800,00 & Recife/PE \\
\hline
\end{tabular}

teorias gerais para apreendê-las [as relações de verdade] eu sou, se quiserem, um empirista cego, quer dizer, estou na pior das situações. Não tenho teoria geral e tampouco tenho um instrumento certo" (Foucault, 1978/2010, p. 229).

A ideia é a de um sujeito ativo, que tem o que diz condicionado ao ato de dizer, pois a linguagem estaria enraizada no sujeito ativo e não na coisa, uma vez que não se trata de um simples produto da memória que reproduziria o real, imitando e duplicando-o. Mas, como uma manifestação daquilo que o sujeito quer, uma tradução desse querer que se torna possível graças às condições dessa linguagem (Foucault, 1984/2010; Veiga-Neto, 2011).

A noção de Foucault (1984/2010) sobre uma possível definição de sujeito remete ao próprio significado da palavra sujeito: ou como uma forma de estar submetido ao outro, numa relação de controle e dependência, ou como ligação com a sua própria identidade, aqui tomada como uma consciência ou autoconhecimento. Em outro momento, Foucault discute como o sujeito está ligado a uma noção de processo, por isso usa muito a ideia de um processo de subjetivação, algo em constante movimento, fazendo-se objetivo dentro dos limites do momento histórico e dos jogos do saber-poder em circulação (Castro, 2009). Mas lembra que a forma-sujeito é uma maneira de experienciar a vida, e compara o processo de subjetivação com uma obra de arte, já que é a capacidade e a possibilidade de se tornar inteligível a partir de certas características temporais, numa construção constante e datada (Foucault, 1984/2014). Nas suas palavras:

[...] será a criação de novas formas de vida, de relações de amizades, na sociedade, na arte, na cultura, novas formas que se instaurarão através de nossas escolhas sexuais, éticas e políticas. Devemos não somente nos defender, mas também nos afirmar, e nos afirmar não somente como identidades, mas como força criadora. (Foucault, 1984/2014, p. 252)

Outra questão a ser discutida, já que se seguiu esse fio condutor, era quanto ao corpus da pesquisa. Corpus, em pesquisa, é o conjunto de dados tomados como objeto de uma pesquisa com objetivo de se proceder às análises.

Foucault aborda os discursos considerando-os como organizações de sentido que circulam como verdades a partir de uma articulação com o saber-poder, e se organizam funcionando como dispositivos que, em última instância, participarão no processo de subjetivação, dando a condição para a formação dos indivíduos em sujeitos historicamente ancorados.

Foucault (1975/2010) afirma que há uma dificuldade de se organizar um corpus de pesquisa na perspectiva de seus estudos, pois a preocupação centra-se muito mais nos discursos que emergem e circulam em certos períodos históricos, do que na eleição de objetos de pesquisa específicos. Destaca que seria impossível levantar todos os discursos em determinado tempo sobre algum objeto de pesquisa. A eleição é muito mais no sentido estratégico político, atentando-se, sobretudo, para as descontinuidades históricas de certos discursos ou regimes de verdade. A preocupação é com a possibilidade de que a eleição de um objeto seja um caminho para uma possível redução do problema à naturalização dele.

Não se trata, pois, de uma análise do discurso no sentido tradicional e consagrado, mas de uma analítica do sujeito, que deve ser tomada sem se desconsiderarem os aspectos de um processo que se dá pela articulação entre regimes de verdade e formas éticas de relação consigo e com o outro. Se quiserem, uma genealogia do sujeito. 


\section{Biopoder e Biopolítica: Uma Aproximação ao Campo das Subjetivações}

Foucault aponta o século XIX como o momento de surgimento do fenômeno da assunção da vida pelo poder, entendendo que houve "[...] uma tomada de poder sobre o homem enquanto ser vivo, uma espécie de estatização do biológico ou, pelo menos, certa inclinação que conduz ao que se poderia chamar de estatização do biológico" (Foucault, $1976 / 2000$, p. 286). Dessa maneira, ele está tomando o problema da soberania, entendendo-a sob o ponto de vista do direito sobre a vida e a morte como atributo fundamental (Foucault, 1976/2000).

Seria o saber médico o equivalente aos soberanos na vida moderna, que regem através do biopoder? Suas prescrições parecem ganhar o cunho de ordem, e são tomadas como verdade absoluta. Aqui, tem-se, por exemplo, com Agenor, 30 anos, um dos sujeitos da pesquisa, a forma como a orientação do profissional médico parece atingi-lo como uma determinação:

Esse é que é o problema. Não é a questão de conviver, porque eu tô vivendo muito bem, graças a Deus. E eu vou até quando Deus quiser. Aí, um dia eu disse: 'Eu vou viver até quanto tempo?'. Ela [a médica] fez: 'Você se medicando, você vai viver até cem anos. Até quando você puder. Porque o HIV não mata. O que mata é a sua imunidade. Se você não se tratar...'. Ela tava até explicando. Aí foi que eu abri a cabeça, que a minha cabeça tava fechada. Aí, fiz o exame, tô tomando o medicamento. (Agenor, 30 anos)

Este trecho da fala de Agenor pode servir de ilustração para o entendimento da torção que foi feita nos discursos da modernidade, nos quais a manutenção da saúde tornase um aspecto central na determinação das ações sobre a população. A argumentação segue no sentido do paradoxo que é colocado, pois o soberano não poderia fazer viver, mas sim morrer. Porém, se há um poder sobre a morte, então a vida está subordinada. O poder de matar é que faz exercer o direito sobre a vida: uma lei da espada! "É o direito de fazer morrer ou de deixar viver" (Foucault, 1976/2000, p. 287). Assim, para Foucault, fazer morrer e deixar viver passa a ser o direito de soberania, e esse irá perpassar, infiltrar e modificar um direito e fazer exatamente o inverso, pois esse direito passará a ser o de fazer viver e de deixar morrer (Foucault, 1988).

A medicação, lastreada no discurso médico-científico, passa a ter o poder de fazer viver? Procede com a manutenção da vida, garantindo-a, através dos cuidados de si? E Agenor continua, questionando-se e refletindo sobre o que deve fazer. Mas pergunta-se se com tais orientações médicas teria garantias:
Tô fazendo exame. Todo ano eu faço exame, renovo exame, hemograma, tudo direitinho. Peço a ela, entendeu? Mas aí vai até quando der. Quando não der, Deus me leva ou eu... Não sei. A gente tem que se acostumar com tudo, porque todo o ser humano vai morrer. Não importa a maneira, a doença. (Agenor, 30 anos)

O saber científico ganha, nesse período, um lugar de centralidade que se desenvolverá em um longo processo. É no campo da manutenção da vida que será legitimado este poder, lançando essa discussão para o campo da filosofia política. O importante, para Foucault (1976/2000), é como o campo do pensamento político começa a problematizar a vida e os corpos. O que se constitui como o foco do pensamento de Foucault é o nível dos mecanismos, das técnicas e das tecnologias de poder. Assim, ao longo dos séculos XVII e XVIII, vimos surgir técnicas de poder que se centravam no corpo: o corpo individual.

Essa genealogia realizada por Foucault visava a introduzir o surgimento de outra técnica não disciplinar que emergirá a partir das condições iniciadas com as técnicas disciplinares do trabalho, uma técnica sobre os corpos; essa nova técnica incidirá sobre a vida dos homens: “[...] ela se dirige não ao homem-corpo, mas ao homem vivo, ao homem ser vivo; no limite, se vocês quiserem, ao homem espécie" (Foucault, 1976/2000, p. 289).

A técnica disciplinar visa à regência da multiplicidade dos homens que, em última instância, redundam em corpos individuais que precisam ser vigiados, disciplinados, treinados, utilizados e punidos. Porém, a nova tecnologia tem como elemento de ação não os corpos individuais, mas quando esses se transformam em massa global, afetada por processos de conjunto, que são próximos da vida: a morte, o nascimento, a produção, a doença, entre outros.

Foucault (1976/2000) passará a pensar em termos de biopolítica:

Trata-se de um conjunto de processos como a proporção dos nascimentos e dos óbitos, a taxa de reprodução, a fecundidade de uma população, etc. São esses processos [...] [que] constituíram, acho eu, os primeiros objetos de saber e os primeiros alvos de controle dessabiopolítica. É nesse momento, em todo caso, que se lança mão da medição estatística desses fenômenos com as primeiras demografias. [...] em suma, se vocês preferirem, o mapeamento dos fenômenos de controle dos nascimentos tais como eram praticados no século XVIII. (Foucault, 1976/2000, p. 290)

A biopolítica retirou dos seus primeiros objetos de conhecimento o necessário para se debruçar sobre um novo campo de intervenção que começa a se configurar para a articulação de seu poder: a população. A população precisa ser abordada a partir de outro referencial. Não se trata 
somente de incidir sobre o indivíduo-corpo, mas sobre um corpo múltiplo que:

[...] se não infinito pelo menos necessariamente numerável. A biopolítica lida com a população, e a população como problema político, como problema a um só tempo científico e político, como problema biológico e como problema de poder, acho que aparece nesse momento. (Foucault, 1976/2000, pp. 292-293)

A gerência da vida, para Foucault (1988), está ligada ao problema moderno da governança. Se antes o soberano tinha o poder de fazer morrer para, por exemplo, protegerse de insurgências e ameaças, no Estado moderno, vai aparecer o seu reverso, a sua forma positivada como um direito sobre o corpo social para manutenção e garantia da vida com a sua majoração e multiplicação, além de controle e disciplinarização. Agora, a questão não é mais a soberania jurídica, mas a biológica, aquela que pode afetar uma população (Foucault, 1988).

Essa governança, explica Foucault (1988), desenvolver-se-á a partir do século XVII sob duas formas que não se excluem, mas estão diretamente ligadas, às quais ele chama de polos. O polo centrado no corpo-máquina, que se interessa pela sua manutenção e otimização, mas se operacionaliza através da disciplina, porque precisa de corpos dóceis - aqui se tem o biopoder em ação. E o outro polo, o qual, segundo o autor, formou-se mais tarde, nos meados do século XVIII, centrando-se no corpo-espécie (o suporte para os processos biológicos), que operava sobre os processos coletivos ou de população, controlando os fenômenos de nascimento e mortalidade, como a duração da vida e a sua longevidade - aqui há intervenções e controles na forma de uma biopolítica da população. Em resumo, temos a disciplinarização dos corpos (o biopoder) e as regulações da população (a biopolítica) (Foucault, 1988).

Surgem, no final do século XVIII e início do XIX, outras ramificações desses dispositivos de poder e disciplinar. Serão eles os problemas advindos do relacionamento dos homens com os próprios homens e desses também com o meio. "Eu chamo 'governamentalidade' o encontro entre as técnicas de dominação exercidas sobre os outros e as técnicas de si" (Foucault, 1988/2014, p. 266).

Foi feito até aqui, com Foucault, a circunscrição de um conceito importante para essa discussão, o conceito de biopolítica. Além disso, tentou-se expandi-lo para pensar como esta ideia serve para se pensar como a população e os processos de saúde e doença são tomados, não somente como objeto de estudo, mas também como possibilidade de disciplinarização e controle. É a politização do indivíduocorpo (Castro E., 2009).

\section{Pensando a AIDS e a Biopolítica}

A questão da medicação ganhou, no tratamento do HIV/AIDS, um lugar de destaque. Tomar corretamente a medicação parece que se transformou em sinônimo de garantia de saúde e de vida.

[...] Porque hoje eu já recuperei quatro quilos. Consegui o tratamento, bem, assim... Segui regras, como a médica pediu, me aconselhou. Vi as consequências, mais tarde, se eu não tomasse a medicação. Aí, eu comecei a tomar, normal. (Renato, 33 anos)

Quando se questiona o lugar de importância que a medicação ganhou no tratamento e cuidados com o HIV/AIDS, não se está, de forma alguma, negando ou negligenciando os avanços e benefícios alcançados, haja vista a redução dramática na mortalidade e morbidade dos infectados pelo HIV. Mas quando se ouve pessoas falarem, como Renato, destaca-se de suas falas aquilo que deveria ser uma orientação médica transformada numa organização de formas de viver próprias e corretas, e levanta-se a questão do que a medicação fez com as subjetividades das PVHA.

Toma-se a subjetividade como um processo, um "processo de subjetivação", que tem nas condições históricas um componente importante, pois viabiliza suas formas e possibilidade de inteligibilidade. Pensa-se em como os indivíduos tornaram-se sujeitos quando atravessados por discursos e dispositivos de poder. O discurso médicocientífico parece ser um deles. E esse é claramente presente nas falas das PVHA.

Assim vão surgindo experiências e formas de viver com o HIV e com os medicamentos. São relatos, muitas vezes, de momentos dolorosos:

Eu tive insônia forte, pelo menos, umas quatro noites. De quatro a cinco noites. E ânsia de vômito, eu tive quase em torno de uma semana. É chato demais, até. E quem não é corajoso, logo no começo, se não tiver alguém que incentive, que ajude... De cara, ele vai querer desistir do medicamento. Mas, depois, lógico que depois, em torno de mais de uma semana, aí você vai se habituando. Já vai pegando mania de querer tomar a medicação. Já carrega na bolsa. (Renato, 33 anos)

É duro imaginar alguém precisando tomar quase 30 comprimidos por dia, e claro que isso não é uma exclusividade da AIDS, mas faz pensar em como as vidas dessas pessoas mudaram, e o que foi necessário para se ajustar a essa nova realidade. Para além da realidade da necessidade das drogas, o biopoder, com seu discurso de vida, vai circulando e colocando em ordem a forma de se ter e viver com o HIV.

Diferentes pessoas e diferentes formas de se subjetivar 
diante da situação semelhante:

Na realidade, não tem complicador nenhum. É só tomar o remédio mesmo e acabou-se. Tem os efeitos colaterais que, na maioria das pessoas, não dá. Eu tive com o Kaletra. Ele dá, às vezes, diarreia, às vezes, dor de barriga. Quer dizer, a questão intestinal, pra mim, com ele, não parou. Já faz dois anos e meio que eu tomo e meu intestino não reage bem ao medicamento. Mas, fora isso, nenhuma. (Fred, 38 anos)

Olhe, eu me sinto muito privilegiada, porque eu tomo aqueles negócios e não sinto nada, a não ser a diarreia. Eu não tenho nenhum problema na área gas... digestiva. Digestiva não, gastrite, essas coisas, nada. (Sandra, 65 anos)

A maneira de articulação do biopoder em uma sociedade disciplinar precisa de dispositivos que vão além do controle dos indivíduos em grupos - a população. Também será preciso pensar no seu controle no nível individual. Assim, várias são as técnicas necessárias que agenciam as subjetivações, entre elas o que Foucault aglutinou nas de técnicas de si.

Foucault (1988), no seminário "As Técnicas de Si", discute o problema das regras, deveres e proibições. Aponta para a sexualidade como sendo um dispositivo diferente que não somente procederá com a interdição, mas também no seu modo positivo, de criação de desejos e sentimentos próprios (Foucault, 1988/2014).

Porém, por excelência, esse dispositivo tem como característica a obrigação de se dizer a verdade sobre si, a isso ele chamou de confissão. Reflete Foucault que a dinâmica de proibição e, ao mesmo tempo de falar sobre algo, é bem característica da sociedade do biopoder. Aqui, Foucault está preocupado em entender, a partir da sexualidade, como se "criou" um sujeito que era obrigado a dizer a verdade, e não somente aquela que era proibida, mas uma verdade sobre si para se possibilitar aceitar a interdição (Foucault, 1988/2014, 2010).

O biopoder não fez diferente com a AIDS. A verdade parece ser algo sempre perseguido e vigiado. Essa verdade do sujeito da AIDS aparece, dentre outras formas, através de seus marcadores biológicos, como aqueles obtidos através de exames laboratoriais que descortinam a verdade sobre a biologia ideal, transfigurada na forma de saúde do indivíduo, que precisa estar atento e regular o próprio funcionamento do corpo. Herbert, 33 anos, exemplifica isso quando diz:

Eu venho sempre... Venho sempre. Dra. X. me encaminha muitas vezes, até porque a taxa, uma vez ou outra, dá uma oscilada... O triglicerídeo, a glicose... Ela sempre... sobe um pouquinho, depois fica normal... Aí eu passei um tempo, eu mudei a alimentação, aí depois voltei, porque não dá pra viver sem sal e sem açúcar. (Herbert, 33 anos)

Esse saber sobre si, para Foucault, era efeito de vários outros campos, como a economia, a medicina, a psiquiatria, a biologia e a criminologia; são jogos de verdade que precisam ser analisados para a compreensão das formas de subjetivação. Para Foucault, o conhecimento sobre si seria, nesta realidade histórica da modernidade, a possibilidade, através das formas de subjetivação, de se alcançarem estados de felicidade, pureza, sabedoria, perfeição e imortalidade. Os jogos de verdade dão as condições para que as subjetivações se formatem, não somente como aptidões, mas como atitudes mesmo (Foucault, 1988/2014).

Foucault vai percorrer um grande caminho histórico com a sua genealogia do cuidado de si, partindo da filosofia greco-romana, passando pela espiritualidade cristã e seus princípios monásticos, até chegar à modernidade. Primeiro ele destaca entre os gregos o preceito conhecido como "cuidados de si" ou "preocupar-se consigo" (epimelesthaiseautou). Esse diria respeito a um importante princípio das cidades (polis) e das regras de conduta da vida social, o que ele virá a reconhecer como a arte de viver, pois destaca que foi um princípio que ficou obscuro pela ideia de um conhecer a si mesmo (gnothiseautón). Porém, o princípio do conhecer-se a si mesmo está subordinado, primeiro, ao cuidado de si. Em última instância, cuidar de si é cuidar da cidade (Foucault, 1988/2014).

A moral cristã, alguns séculos depois, vai recuperar este princípio do cuidado de si, de forma diferente. Dentro do asceticismo cristão, o conhecer-se a si mesmo tornar-se-á uma prática constante, não para ocupar-se da cidade, mas de si mesmo, depreendendo-se da carne, com virgindade do coração e do corpo para recuperar a imortalidade de que as questões da carne os privam.

Foucault $(1988 / 2014,2010)$ procurava entender como o princípio do conhecer-se a si mesmo veio a sobrepor-se, nas culturas ocidentais, ao do cuidado de si. Ele vai explicar que, na busca por uma moral rigorosa e princípios austeros, preocupar-se consigo mais do que com o outro levaria a uma noção de imoralidade, um meio de escapar às regras possíveis. Dentro da moral cristã, é na renúncia a si que se alcançaria a salvação. Dessa forma, observa-se a construção da noção de uma lei externa como o fundamento da moral. "Somos herdeiros de uma moral social que fundamenta as regras de um comportamento aceitável sobre as relações com os outros" (Foucault, 1988, p. 270).

Pode-se identificar isso também na fala de algumas pessoas, depois de ter sabido de seu HIV, que, na tentativa de retomar uma vida afetiva e sexual, deparam-se com o dilema da pureza através da preocupação em infectar o outro com o "vírus mortal".

Mudou minha forma de pensar; o medo de me contaminar 
com outras doenças; a preocupação com a minha saúde, também, mudou; o respeito pelo próximo mudou também, porque eu não quero pros outros o que eu não quero pra mim, e, a perspectiva de realizações. (Fred, 38 anos)

Finalmente, houve uma alternância na hierarquia dos princípios antigos de cuidar de si e de conhecer a si. No início, com a cultura greco-romana, conhecer a si era uma mera consequência do cuidar de si; no mundo moderno, haverá a elevação à última potência do conhecer a si como um princípio fundamental.

No asceticismo cristão, caberá ao indivíduo reconhecer em si seus pecados e buscar um bispo, por exemplo, para pedir a sua penitência. Foucault (1988) vai dizer que é nessa eterna vigilância de si pelo ato da penitência que se adquire o status de penitente, uma forma de subjetivação, uma forma de ser no mundo. Ao exibir o sofrimento e ostentar a modéstia, compõe-se o princípio da punição. Manter-se "limpo e puro" é o objetivo cristão. É um dever de vigilância do sujeito.

Esse passeio pelas continuidades e descontinuidades da história é uma das formas de Foucault proceder com a sua genealogia. Tem por fim o entendimento de como as formas de ser e de administrar as subjetividades se vão formatando, incorporando ou transformando, a partir de certas práticas históricas. Um exemplo desses princípios na modernidade, como foram absorvidos e transformados, é o modelo médico em que o doente fala (confessa) suas feridas ao médico que oferece a cura. Ou o modelo jurídico do julgamento, no qual, "tudo" é dito ou confessado ao juiz, que proclama a sua pena (Foucault, 2010; 1988/2014). Dessa maneira, a partir dessa transformação histórica, observa-se como várias formas de ser e de viver foram formatadas em técnicas de si. A tradição cristã é uma de suas variações históricas:

O cristianismo exige outra forma de obrigação de verdade, diferente da fé. Ela exige de cada um que saiba quem se é, isto é, que se dedique a descobrir o que acontece em si, que reconheça seus erros, admita suas tentações, localize seus desejos; cada um deve, em seguida, revelar essas coisas seja a Deus, seja aos outros membros da comunidade, levando, assim, testemunho, publicamente ou de maneira privada, contra si mesmo. Um elo existe entre as obrigações de verdade que concernem à fé e as que dizem respeito ao indivíduo. Esse elo permite uma purificação da alma impossível sem o conhecimento de si. (Foucault, 1988/2014, p. 287)

Voltando à questão das PVHA, pode-se ver que, com todas essas orientações e prescrições médicas, a tomada dos medicamentos e as formas de viver vão fazendo surgir sujeitos que, na arte de viver, vão construindo, moldando e transformando suas formas de ser e de se subjetivarem. A forma como administram suas vidas é um dado importante e, no caso específico deste trabalho, a forma como administram o uso de sua medicação. Como fazer para dar conta do imperativo de tomar o remédio necessário à manutenção da vida, e viver a vida dentro das possibilidades de cada um? Renato, 33 anos, resume da seguinte forma sua relação com o medicamento, quando perguntado se é difícil administrar tudo isso:

Demais! Tem noite que eu vou dormir sem tomar remédio. Mesmo o meu celular despertando. Aí, já passou. Aí, eu fico cá comigo: 'Será que eu tomo?'. Mas tem que ser no horário certo. Eu não posso passar duas, três horas, segundo o aconselhamento médico. (Renato, 33 anos)

Parece que é uma luta diária contra um jeito de ser que não está acostumado com aquilo como realidade, uma realidade que a todo tempo tenta se impor:

O que é mais fácil e mais difícil? Pra um portador de vírus HIV, nada é fácil. Nem a medicação. Nada é fácil. Mas a gente tenta... A gente tenta se habituar. Mas não é fácil. Toda vez que você vai tirar o medicamento da coisa [do frasco], você olha pra ele, você toma, você se lembra, né? (Agenor, 30 anos)

Assim, segue a vida com seus remédios. Qual o objetivo de tudo isso? Como tornar tudo isso possível? Herbert, Sandra e Fred nos descrevem suas estratégias:

Eu geralmente espero dar o horário, tomo para depois sair. Se for algum evento que tenho que sair mais cedo, aí eu ponho a mochila nas costas e levo o remédio. Aí, eu faço isso. Durante o dia, pra onde eu vou, já ando com ele, velho! (Herbert, 33 anos)

Eu boto aquelas pílulas, aqueles tijolinhos na boca, e vou-me embora. Mas o chato mesmo são os horários. [...] Quando eu cheguei aqui no sistema, no SAE, o remédio que eu tomo - que é o mesmo desde o início - ainda precisava ir pra geladeira. Hoje, não precisa mais. Quer dizer, logo depois não precisa mais, o que dá uma certa independência a você de mobilidade. Porque quando ia viajar, você tinha que levar um isopor com gelo, com nem sei o quê. Vai pra casa de alguém tem que pedir pra botar na geladeira. Era uma coisa meio incômoda. (Sandra, 65 anos)

Eu só deixo de tomar quando eu tô com alguém que não sabe e eu não tenho aquela condição de tomar. É muito raro acontecer. Assim, por esquecimento, não. [...] $\mathrm{Na}$ frente dessa pessoa, não dá. Então, eu passo da hora. Aí, quando eu tô só, eu vou e tomo. Geralmente, tá no bolso já esperando, doido pra ser tomado, mas, esperando uma oportunidade certa. (Fred, 38 anos) 
Se a adesão ao tratamento é considerada como algo vital no tratamento dessas PVHA, cabe-se perguntar o que é adesão. Assim, evocando as palavras do poeta português Fernando Pessoa (1888-1935), em seu poema de 1914, talvez seja possível retratar as subjetividades necessárias a um determinado tipo de adesão ao tratamento:

Navegadores antigos tinham uma frase gloriosa:

"Navegar é preciso; viver não é preciso".

Quero para mim o espírito [d]esta frase, transformada a forma para a casar como eu sou:

Viver não é necessário; o que é necessário é criar. Não conto gozar a minha vida; nem em gozá-la penso.

Só quero torná-la grande, ainda que para isso tenha de ser o meu corpo e a (minha alma) a lenha desse fogo.

Só quero torná-la de toda a humanidade; ainda que para isso tenha de a perder como minha. Cada vez mais assim penso.

Cada vez mais ponho da essência anímica do meu sangue

o propósito impessoal de engrandecer a pátria e contribuir

para a evolução da humanidade.

É a forma que em mim tomou o misticismo da nossa Raça.

Através das palavras de Pessoa, vislumbra-se o processo de viver com HIV/AIDS e a importância à adesão ao tratamento como o "tomar o remédio é preciso". Mas como viver com isso?

Eu consigo administrar [tomar o remédio no meio de um monte de pessoas]. Mas, assim... É chato. Eu digo assim, que é chato. Já pensou, você tá do lado de alguém, aí abre assim 'pum', um monte de remédio na mão... Você... Todo mundo vai olhar aquilo... Eu mesmo olhava um negócio daquele. Assim, encher a mão de remédio e tomar! (Herbert, 33 anos)

E tomar o remédio se torna algo que sempre levanta questionamentos e traz dificuldades:

Os experientes dizem que ninguém morre de HIV. O que mata é o sistema imunológico, que fica... Aí abre a porta pra tuberculose. Se você fuma, se você não se trata, se você... Aí vem aquela coisa toda. Mas se você se cuidar direitinho, eu acho que, se prevenir direito, eu acho que você vive um pouco. Acredito que não mata, não! (Agenor, 33 anos)

E o remédio passa a ser o referencial da saúde e é vigiado e medido, tomado como a confissão biológica das PVHA. Fred, 38 anos, fala como fica vigilante, e Sandra, 65 anos, sabe sobre os referenciais de seus exames para avaliar sua saúde.

Vigilante. É. Agora mesmo, fiz... O exame fazia cinco meses, já tava assim. E aí? Mas tava tudo certinho. Mas você fica preocupado, se o seu CD4 tá legal, se sua carga viral continua negativada. Essas coisas. (Fred, 38 anos)

Mas a minha carga viral é indetectável, o último CD4 que eu tive estava em 1.258... Então, estou me considerando muito bem. Agora, nem por isso a gente vai relaxar. (Sandra, 65 anos)

Em 1982, Foucault (2010), na aula de 24 de fevereiro do curso sobre a hermenêutica do sujeito, aborda a conversão a si (o princípio de "voltar o olhar para si mesmo"). Essa conversão a si não consiste somente em organizar um conhecimento de si buscado num movimento de interiorização. O movimento de "voltar o olhar para si" compreende, também, conhecer o mundo.

É, para ele, um processo de espiritualização do saber no mundo. Trata-se de, alegoricamente, um sujeito recuar a um ponto de contemplação mais geral deste mundo para poder ter a perspectiva de que ele mesmo está neste mundo, e o quão ínfimo é o seu lugar ali.

A espiritualização do saber seria um rastro genealógico de como a perspectiva de Foucault aponta para os elementos que podem dar forma à subjetivação: o componente histórico indissociável da experiência.

Foucault, nesta aula, está discutindo uma ética antiga, destacando como exemplo, alguns parástematas de Marco Aurélio. O parástema, em grego, não designa um preceito, mas algo que está ali para ser sempre guardado e olhado, algo que norteia o ser-no-mundo, como princípio de verdade e de comportamentos. "Portanto, é alguma coisa ou coisas que devemos ter no espírito e guardar sob os olhos" (Foucault, 2010, p. 261). Devem "fazer" parte de uma forma de subjetivação que aponta Foucault como característica deste tempo. Não somente como imposição limitadora, mas como possibilidade criadora.

Assim, vê-se que o processo de adesão não precisa e nem vai sendo tomado somente como uma imposição às subjetividades das PVHA. A tensão entre o prescrito e o vivido começa a aparecer nessas pessoas, no momento em que exercitam a sua liberdade em consonância com certos ditames do tempo em que vivem, e que não podem e nem 
devem ser esquecidos - os benefícios das medicações.

Novas formas de lidar e administrar a medicação e a doença vão aparecendo. Agenor, 30 anos, diz:

Faz pensar muito. Muito. Eu faço pensar assim, eu penso e digo: "Meu Deus, é, remédio pra combater o vírus do HIV. E se fosse um remédio pra diabete? Se fosse um remédio pra o câncer?". Eu dou graças a Deus. Deus me perdoe se eu estou sendo... Não sei se eu tô pecando. Mas, eu agradeço a Deus por ter me dado esse tipo de assunto. Por quê? Porque é mais fácil. Eu acho muito mais fácil. (Agenor, 30 anos)

Parece que Agenor consegue afastar-se um pouco da visão mortífera da AIDS e começa a conviver de uma outra forma, talvez menos angustiante. $\mathrm{E}$ isso também vai refletir-se na forma como lida com a adesão ao tratamento e a medicação. Isabela, 38 anos, quando perguntada, falou de como sua vida mudou após o início do uso da medicação:

É. Pelo contrário, eu engordei mais. Peguei mais três quilos. Como de tudo, ando, brinco, converso, tomo banho de praia, vou pra shopping, vou pra onde eu quero. Faço o que eu quero. Não mudou nada. Eu acho que melhorou mais ainda. (Isabela, 38 anos)

É como se essas pessoas tomassem esta realidade e as transformasse em algo positivo. Mas parece, também, que o outro lado de ser uma "doença" não desaparece totalmente. Sandra, 65 anos, diz:

Então, às vezes, eu me pego fazendo todas essas perguntas que eu tô the fazendo aqui, agora e, também, logo em seguida, eu digo assim: 'Peraí, calma. Não adianta eu ficar lá na frente, porque isso eu não sei como vai ser. Pode ser que eu, hoje, vá dormir e amanhã não acorde. Então não vai ter ninguém pra trocar frauda, não vai precisar de nada disso. Então volta.' Eu tenho procurado viver um dia de cada vez, realmente, e da melhor maneira possível. (Sandra, 65 anos)

Seguindo esse caminho, é possível tentar definir a adesão a partir do que a própria Sandra constrói, refletindo sempre com a irreverência que lhe é peculiar. Ela faz graça de si mesma, da sua condição e da AIDS. Ela consegue brincar e fazer brincadeira com o sofrimento e o medo. Mas não é brincando que, muitas vezes, se diz a verdade? Assim, ela ensina, a partir de sua própria experiência de ser uma PVHA, o que até agora assimilou como adesão, e tomou como uma forma de viver. Diz ela:

Adesão, pra mim, é aderir, abraçar - abraçar no sentido de acolher - o outro como ele está. Porque [é] esse acolhimento que tem a ver com adesão, é que permitirá ao sujeito a encarar esse tratamento. Porque é pra sempre. Por enquanto, é pra sempre. Você não vai, não adianta você burlar. Quer dizer, burlar você ainda pode, se você quiser morrer ou qualquer coisa outra, mas você precisa aderir, juntar, grudar, se ligar, em todas as possibilidades pra você encontrar forças para se tratar, que não é só engolir o remedinho. É muito isso, mas você precisa cuidar de sua cabeça, do físico, das suas relações, tudo. Então, a adesão é um negócio muito mais amplo do que essa pequena palavra comporta. Tem coisas, tem conceitos mais elaborados. Mas é isso, aderir é você olhar pro outro. [...] Adesão é um negócio complicado. (Sandra, 65 anos)

Algo que sempre chamou a atenção é como o grupo de adesão, que funcionava um dia semanalmente com encontros entre os usuários do $\mathrm{SAE}$, que preferiam denominar o grupo de adesão ao medicamento, como grupo de adesão à vida. Sim, pois viver com HIV/AIDS parece que vai além da simples ingestão de medicamentos e cumprimento de protocolos clínico-laboratoriais. Essencial para a sobrevivência ao HIV, a adesão precisa ser vista para além do uso correto de uma medicação, por mais importante que ela seja.

\section{E, Finalmente, Tomo ou Não Tomo o Remédio? - Considerações Finais}

Adesão implica rever as formas de relacionar-se consigo e com o outro, considerando o mundo disponível ao seu redor; é lidar com as adversidades de um quadro de doença crônico, mas também é conseguir achar um caminho próprio e único que possa fazer sentido para o sujeito.

Discutiu-se, neste artigo, como o discurso médicocientífico tornou-se central na modernidade e nos processos de subjetivação. Assim, o objetivo deste trabalho era de discutir e problematizar como a medicação tornouse central no tratamento de PVHA, e o ponto-chave na medição do processo de adesão por uma pessoa que está sendo acompanhada no SAE.

É inegável e os números mostram como a mortalidade entre as PVHA caiu após o início da administração universal da TARV. Isso aconteceu no mundo e também no Brasil. A adesão foi abordada a partir de dois prismas: o primeiro sustenta que a adesão é a capacidade de manter o uso de medicação (frequência, dosagem e horário) de acordo com a prescrição médica, considerando que a falha do tratamento estaria ligada ao uso inconsistente deste esquema medicamentoso, ou o surgimento de resistência a esta medicação (Chaiyachatia et al., 2014). Por outro lado, o Programa Brasileiro de DST e AIDS (Ministério da Saúde, 2007) vai chamar a atenção para esse processo de adesão, que vai além da ingestão de medicamentos. Compreende também um fortalecimento das PVHA, assim 
como suas relações com os serviços de saúde, maior acesso à informação e adequação da adesão aos hábitos e estilos de vida de cada um.

Segundo Ferreira Neto e Kind (2010), o programa brasileiro de saúde se pautou numa lógica sanitarista, em que a prescrição de estilos de vida foi um dos pontos centrais. A partir disso, já se pode pensar como esse panorama pode fazer circular discursos e propiciar as condições bem específicas para a formatação de certos processos de subjetivação cujo funcionamento biológico ideal parece ser sempre a meta a alcançar-se.

Tomaram-se como referenciais de diálogo as ideias de Michel Foucault, principalmente aquelas concernentes ao biopoder e à biopolítica. $\mathrm{O}$ primeiro seria uma característica das sociedades normalizadoras modernas, enquanto o segundo, o seu dispositivo operacional, que atua eminentemente sobre os processos de subjetivação.

Eles produzirão corpos dóceis e sujeitos normalizados que trarão segurança à sociedade. Essa implementação se daria a partir da possibilidade de governabilidade em dois níveis, o grupal, a partir das técnicas políticas, com a vigilância e o controle estatal, assumindo um cuidado com a vida; e, no plano individual, com as tecnologias de si que vigiam as formas de ser no mundo.

Foi possível, então, a partir das pessoas entrevistadas, entrar em contato com o mundo delas, a fim de discutir como a AIDS foi politicamente organizada para cumprir o seu papel de controle dos corpos e das sexualidades.

Agerência da vida, como apontou Foucault (1988/2014), fica bem evidente em como este discurso médico-científico coordena as ações dos profissionais de saúde nos serviços de tratamento das PVHA e nas suas prescrições. Renato, 33 anos, por exemplo, descreve a sua forma de viver agora subordinada a tal discurso: "Consegui o tratamento, bem, assim... Segui regras, como a médica pediu, me aconselhou". Tal forma de colocar o tratamento aponta para a maneira como o discurso da AIDS foi articulado por vários dispositivos e passou a governar a vida.

E o interessante é que, não somente das pessoas infectadas pelo HIV, mas também das que não são. Cuidar de si, nesse caso, mais ligado a um saber de si, é também cuidar do outro. Não de uma maneira altruísta, mas como uma forma de normalizar os corpos e vigiá-los. Quando a pessoa com HIV segue um tratamento, ela não está somente cuidando de si, mas da saúde do outro e, assim, da população.

A prescrição de medicamentos não é, per si, uma coisa ruim. Longe disso, pois se viram todos os benefícios alcançados. A qualidade de vida das PVHA melhorou e a mortalidade pela AIDS diminuiu. Mas destaca-se também a quantidade de efeitos colaterais que, junto com o benefício, trouxe também outros sofrimentos e males. Várias pessoas relatam como sofrem com esses efeitos indesejados, mas necessários para a obtenção de uma saúde melhor. Mas o que é saúde? Viver mais, mesmo que sofrendo? A prescrição indiscriminada de medicação e de estilos de vida pode ser também lida como outra forma de gerência da vida pelos soberanos. A pessoa que toma a medicação é consultada se quer manter tal prescrição? Mas como pode ela discordar de uma manutenção da vida se ela foi assujeitada para funcionar em seu nome? É melhor viver mais ou viver melhor?

Evidentemente que esta é uma discussão complexa, pois se aborda aqui vida e morte, e morte é algo que não parece facilmente aceita, principalmente na sociedade medicalizada. A questão, de novo, não é a da eficácia do medicamento, mas como as pessoas estão vivendo e sofrendo com esta cura/tratamento sem serem consultadas ou mesmo participadas na hora da escolha do seu tratamento, que terá uma consequência imediata e direta sobre a forma de viver suas vidas. A medicação parece ser garantia de saúde e vida.

Focou-se nos processos de subjetivação. $\mathrm{O}$ que se discutiu aqui é como a AIDS, funcionando como um dispositivo, vem promovendo formas de ser e de viver. A medicação tem uma implicação no estilo de vida dessas pessoas. Elas passam, agora, a viver dentro dos ditames de uma vida saudável e com hábitos saudáveis.

Pessoas falaram de insônia, ânsia de vômito e da ingestão de uma quantidade enorme de comprimidos. Como essa pessoa fará para tomar tantos medicamentos sem chamar a atenção sobre si? Pequenas coisas que são causadas ainda pelo estigma e preconceito em relação à AIDS. Estereótipos em relação às pessoas "doentes", porque quem toma remédio são os doentes. E quanto mais pílulas, mais doente?

Porém, nem todos reclamam e veem isso como algo que atrapalha. Observaram-se pessoas falando nas estratégias criadas para se viver com a situação específica, de uma forma criativa. Isabela diz, muito conformada, que se o remédio dá tontura, então toma à noite, antes de dormir. Já Fred, 38 anos, diz: "Na realidade, não tem complicador nenhum. É só tomar o remédio, mesmo, e acabou-se". Adaptado, vê na sua obrigação de tomar remédios algo normal, e incorpora a sua vida sem maiores reclamações. Simplesmente faz o que deve ser feito.

É o poder funcionando e circulando, como entende Foucault (1988/2014), proibindo algumas coisas, mas possibilitando a criação e o surgimento de outras formas de viver. Assim, a vida é construída como uma arte, onde se cria algo novo a partir daquilo que lhe é imposto. Isso é uma estilística da existência. As técnicas de si, como diz Foucault, servem como moldes na forma de subjetivação, promovendo conformações à norma e, outras vezes, subvertendo-as.

Não é possível esquecer, porém, aquilo que Foucault (1988) identificou e discutiu principalmente a respeito da sexualidade, da obrigação de confissão e de dizer a verdade sobre si. A forma como as PVHA têm sua saúde 
biológica acompanhada e medida pode também servir como parâmetro para se definir suas escolhas em conformidade com os ditames dos "soberanos" que regem a vida. Se estão tomando corretamente a medicação, isso aparecerá nos exames. Se não, vem a pergunta: "o que você está fazendo com a sua vida?". Mas a vida não é dela?

A adesão implica seguir certa rotina de visitas ao médico, a realização de exames laboratoriais e a ingestão de medicamentos. São esses dados observados pelo profissional médico que irão determinar se a vida desse sujeito está ou não sendo vivida corretamente de acordo com os ditames do "soberano". E assim, sutilmente, a vida vai sendo vigiada e regulada. São os jogos de verdade colocados em prática, formatando atitudes.

Na AIDS, toda essa informação que a PVHA deveria ter sobre sua doença e sobre si mesma faz aparecer a tensão identificada por Foucault (1988/2014) desde a antiguidade, quando o saber de si sobrepõe-se ao cuidado de si. Essa é a crítica aqui. O saber de si deve estar subordinado ao cuidado de si. E não incorporado como uma verdade sobre si que está a serviço da administração da vida pela biopolítica.

Como identificou Foucault (1988/2014), a moral cristã fará uma torção nesta lógica, e a incorporará, agora, como certa pureza e retidão na forma de viver. Ora, se a AIDS é identificada como uma doença sexualmente transmissível, ela também fala das sexualidades e práticas sexuais, e ela precisa ser vigiada e modelada. Os corpos precisam ser adestrados e docilizados.

Fred, 38 anos, reproduz tudo isso muito fielmente: Mudou minha forma de pensar; o medo de me contaminar com outras doenças; a preocupação com a minha saúde, também, mudou; o respeito pelo próximo mudou também, porque eu não quero pros outros o que eu não quero pra mim. (Fred, 38 anos)

A retidão de uma conduta na vida está aqui claramente expressada, está subjetivada. Além disso, tem-se também o instituto da confissão, em que os pecados precisavam ser confessados ao bispo. Agora, é ao médico que as "pessoas doentes" têm de se reportar. E buscar aconselhamento e penitência. Seriam os remédios e os tratamentos a forma biopolítica de se penitenciar? AAIDS vai, assim, cumprindo a sua função como um dispositivo sobre a sexualidade e ao estilo de vida das pessoas.

O processo de adesão ao tratamento é, sem dúvidas, algo importante e vital para as PVHA. Sem o medicamento, elas morreriam mais rápido e sofreriam com várias doenças oportunistas. O que se discutiu foi a ideia de adesão como algo que pode ser necessário e construído entre a pessoa medicada e a equipe de saúde. Não somente de biológico é constituído o indivíduo, nem somente de remédio ele vive. As outras dimensões do sujeito, como a social e a psicológica, dentre outras, deveriam também ser levadas em consideração. A adesão deveria ser pensada e sempre problematizada, levando-se em consideração os discursos circulantes e as formas possíveis de vida do sujeito.

É ele quem deveria poder escolher seus caminhos e fazer, com o inevitável, o possível para uma vida melhor. "Melhor" esse que se paute no seu referencial próprio de vida, de verdade e de liberdade. A arte de viver pressupõe a construção de projetos únicos e verdadeiros para cada um. É interessante ver os movimentos subversivos aos discursos e à rede de poder com a criação de estratégias de vida por essas pessoas. Elas podem submeter-se sem se renderem aos ditames da biopolítica que vigia a vida e o bem da sociedade através do indivíduo. Elas podem pôr em tensão essas regras e criar novas possibilidades, sempre.

\section{Referências}

Agamben, G. (2010). Homo Sacer: o poder soberano e a vida nua I. Belo Horizonte: Ed. UFMG.

Castro, E. (2009). Vocabulário de Foucault: Um Percurso pelos seus Temas, Conceitos e Autores (I. M. Xavier, Trad.). Belo Horizonte: Autêntica Editora.

Chaiyachatia, K. H., Ogbuoji, O., Price, M., Suthar, A. B., Negussie, E. K., \& Barnighausen, T. (2014). Interventions to improve adherence to antiretroviratherapyl: a rapid systematic review. AIDS, 28(supl2), 187-204.

Ferreira Neto, J., \& Kind, L. (2010). Promoção de saúde: uma discussão teórica-metodológica a partir de Foucault. In E. Lima, J. Ferreira Neto, \& L. Aragon, Subjetividade Contemporânea (pp. 43-60). Curitiba: Ed. CRV.

Fischer, R. M. (2012). Trabalhar com Foucault-arqueologia de uma paixão. Belo Horizonte: Autêntica.

Foucault, M. (1975/2010). Ditos \& escritos VI: repensar a política. Rio de Janeiro: Forense Universitária.

Foucault, M. (1976/2000). Aula de 17 de março de 1976. In M. Foucault, Em defesa da sociedade (pp. 201-222). São Paulo: Martins Fontes.

Foucault, M. (1978/2010). Mesa redonda em 20 de Maio de 1978. In M. Foucault, \& M. B. Motta (Eds.), Ditos \& Escritos IV: Estratégia, poder-saber (2a. ed., pp. 335351). Rio de Janeiro: Forense Universitária.

Foucault, M. (1984/2010). O Retorno da Moral. In M. Foucault, \& M. B. Motta (Eds.), Ditos \& Escritos V: 
ética, sexualidade, política (2a. ed., pp. 252-263). Rio de Janeiro: Forense Universitária.

Foucault, M. (1984/2014). Michel Foucault, uma entrevista: sexo, poder e política da identidade. In M. Foucault, \& M. B. Motta (Eds.), Ditos \& Escritos IX: Genealogia $d a$ étics, subjetividade e sexualidade (pp. 251-263). São Paulo: Forense Universitária.

Foucault, M. (1988). A história da sexualidade I: A vontade de saber (16a. ed.). Rio de Janeiro: Editora Graal.

Foucault, M. (1988/2014). As Técnicas de si. In M. Focault, \& M. B. Motta (Eds.), Ditos \& escritos IX: Genealogia da ética, subjetividade e sexualidade (pp. 264-296). Rio de Janeiro: Forense Universitára.

Foucault, M. (2010). A Hermenêutica do Sujeito (3a. ed.). São Paulo: Martins Fontes.

Ministério da Saúde. (2007).Diretrizes para ofortalecimento das ações de adesão ao tratamento para pessoas que vivem com HIV e AIDS. Brasília: Ministério da Saúde.

Pessoa, F. (1914). Navegar é preciso. Recuperado de http:// www.casadobruxo.com.br/poesia/f/navega.htm

Veiga-Neto, A. (2011). Foucault \& Educação. Belo Horizonte: Autêntica.

\section{Endereço para correspondência:}

Ricardo Lima

Endereço: Universidade Católica de Pernambuco,

Programa de Pós-graduação em Psicologia Clínica. Rua do Principe, $\mathrm{n}^{\circ}$ 526, Boa Vista. Recife/PE, CEP: 50050-900.

E-mail: ricardomarques_psi@yahoo.com.br

\section{Endereço para correspondência:}

Cristina Almeida

Endereço: Universidade Católica de Pernambuco,

Programa de Pós-graduação em Psicologia Clínica. Rua do Principe, $\mathrm{n}^{\circ}$ 526, Boa Vista. Recife/PE, CEP: 50050-900.

E-mail: crisamaz@gmail.com

\section{Endereço para correspondência:}

Luciana Vieira

Endereço: Universidade Federal de Pernambuco, Centro de Ciências Humanas, Departamento de Psicologia. Av. Prof. Moraes Rego, $\mathrm{n}^{\circ}$ 1235, Cidade Universitária. Recife/ PE, CEP: 50670-901.

E-mail: lufontesvieira@hotmail.com 